\title{
NOVEL PROCESS FOR THE SIMULTANEOUS EXTRACTION AND DEGUMMING OF BANANA FIBERS UNDER SOLID-STATE CULTIVATION
}

\author{
Nicemol Jacob;Parukuttyamma Prema* \\ Biotechnology Division, National Institute for Interdisciplinary Science and Technology (CSIR), Trivandrum, India.
}

Submitted: April 16, 2007; Returned to authors for corrections: October 27, 2007; Approved: January 14, 2008.

\begin{abstract}
Various process parameters for the production of polygalacturonase by Streptomyces lydicus under solidstate fermentation were optimized. The optimum particle size of wheat bran for polygalacturonase production was in the range of 500-1000 $\mu \mathrm{m}$. Initial moisture content of 70\% was found to be the optimum for enzyme production. The most suitable inoculum size was $1.25 \times 10^{5} \mathrm{CFU} / \mathrm{mL}$ and the optimum incubation temperature was $30^{\circ} \mathrm{C}$. Addition of carbon sources resulted in $37 \%$ increase in enzyme yield $(425 \mathrm{U} / \mathrm{g})$, whereas no significant enhancement was obtained on nitrogen supplementation. Maximum enzyme yield was recorded at $72 \mathrm{~h}$. When compared to the initial production medium $(108.5 \mathrm{U} / \mathrm{g})$, the enzyme yield was 3.9 fold after optimization. Solid-state fermentation was effectively employed to develop a novel process for the simultaneous extraction and degumming of banana fibers. Streptomyces lydicus was allowed to grow on wheat bran medium in which banana leaf sheath pieces were incorporated and the fiber bundles were separated after a two-step fermentative process.
\end{abstract}

Key words: Banana fiber degumming, Solid-state fermentation, Polygalacturonase, Streptomyces lydicus, Wheat bran.

\section{INTRODUCTION}

Plant fibers are schlerenchymatous cells with heavily lignified cell walls having a narrow lumen in cross section. Fiber cells are dead at maturity and serve as a support tissue (1). Natural fibers possess several advantages over synthetic fibers such as low density, appropriate stiffness and mechanical properties and also high disposability and renewability (11). Also, they are recyclable and biodegradable (2). Banana fibers can be used for various purposes such as in textile, paper or handicrafts industry. Banana paper is versatile as it is waterproof and stronger than wood-pulp paper, meaning it can be used in packaging and even as a basis for building materials. India is the first banana fruit producer in the world and the yield is 16 million tons per year. After harvesting, the pseudostem of banana is disposed as a waste material. The fiber content of the above material is $54.3 \%$ and can be effectively used as a source of natural fibers.
Banana fibers can be extracted by employing chemical, mechanical or biological methods. Chemical method causes environmental pollution, while mechanical method fails to remove the gummy material from the fiber bundle surface. Biological procedures yield more fiber bundles than the other two procedures without any harm to the environment. The extraction of banana fibers using biological natural retting has already been reported (2). After extracting the fibers, degumming is essential prior to the utilization of fibers. The removal of heavily coated, non-cellulosic gummy material from the cellulosic part of plant fibers is called degumming (16).

Pectinases have a leading role in the degumming of natural fibers by removing interlamellar pectin which acts as a cementing substance between the fibers. Solid-state fermentation (SSF) is an efficient tool for microbial enzyme production including pectinases. The yield of a desired product under SSF depends upon several factors like particle size of the substrate, initial moisture content of the medium,

*Corresponding Author. Mailing address: Biotechnology Division, National Institute for Interdisciplinary Science and Technology (CSIR), Trivandrum, 695019, India. Phone: ++91 4712515 325; Fax: ++91 4712491 712. E-mail: premar51@rediffmail.com 
incubation temperature etc. and hence it is essential to optimize the levels of these factors.

The aim of the present investigation was to study the effect of process parameters and nutrient supplementation on polygalacturonase production by Streptomyces lydicus in solidstate fermentation using wheat bran and to develop a novel process for the simultaneous extraction and degumming of banana fibers utilizing polygalacturonase produced by Streptomyces lydicus.

\section{MATERIALS AND METHODS}

\section{The microorganism}

The novel strain of Streptomyces lydicus MTCC 7505 used in the present investigation was isolated from mangrove sediment (7) and was maintained on starch casein agar slants at $4^{\circ} \mathrm{C}$.

\section{Inoculum preparation}

Broth media used for the preparation of inoculum contained $(\mathrm{g} / \mathrm{L})\left(\mathrm{NH}_{4}\right)_{2} \mathrm{SO}_{4}: 2 ; \mathrm{K}_{2} \mathrm{HPO}_{4}$ : $2 ; \mathrm{KH}_{2} \mathrm{PO}_{4}$ : 2 ; yeast extract: 3 and pectin: 5 ( $\mathrm{pH} 7.0$ ). The strain was inoculated into $100 \mathrm{~mL}$ of the broth in $250 \mathrm{~mL}$ Erlenmeyer flask and incubated for $24 \mathrm{~h}$ at $30^{\circ} \mathrm{C}$ and $175 \mathrm{rpm}$ in a rotary shaker. The inoculum contained $2.5 \times 10^{4}$ colony forming units $(\mathrm{CFU}) / \mathrm{mL}$.

\section{Solid-state fermentation}

Solid-state fermentation was carried out in $250 \mathrm{~mL}$ Erlenmeyer flasks with $10 \mathrm{~g}$ of wheat bran with a particle size of 500-1000 $\mu \mathrm{m}$. The solid substrate was moistened with a solution containing $(\mathrm{g} / \mathrm{L})\left(\mathrm{NH}_{4}\right)_{2} \mathrm{SO}_{4}: 4 ; \mathrm{K}_{2} \mathrm{HPO}_{4}: 4$ and $\mathrm{KH}_{2} \mathrm{PO}_{4}: 4(\mathrm{pH}$ 7.0), autoclaved for $45 \mathrm{~min}$ and inoculated with $5 \mathrm{~mL}$ of broth culture. The final moisture content of the flask was $50 \%$. Flasks were incubated for four days at $30^{\circ} \mathrm{C}$.

\section{Optimization of process parameters}

Various process parameters were optimized such as particle size of the substrate (>300, 300-500, 500-1000 and 1000-2000 $\mu \mathrm{m})$, initial moisture content of the medium $(30,40,50,60,70$ and $75 \%), \mathrm{pH}$ of the moistening solution (5.0, 6.0, 7.0, 8.0, 9.0 and $10.0)$, inoculum size $(2.5,5,7.5,10,12.5$ and $15 \mathrm{~mL})$ and incubation temperature $\left(27,30,33\right.$ and $\left.36^{\circ} \mathrm{C}\right)$. Optimization of initial moisture content was performed, maintaining the concentration of mineral salts constant, varying only the volume of distilled water so that mineral salts should not have any differential influence on growth and enzyme production. Supplementation of the growth media with $1 \%(\mathrm{w} / \mathrm{w})$ of different carbon sources (glucose, galacturonic acid, sucrose, starch and pectin,), 1\% (w/w) of organic nitrogen sources (yeast extract, peptone, urea and corn steep solids) and inorganic nitrogen compounds in terms of available nitrogen $(0.004 \%$, w/w $)\left(\left(\mathrm{NH}_{4}\right)_{2} \mathrm{HPO}_{4}, \mathrm{KNO}_{3}, \mathrm{NH}_{4} \mathrm{HCO}_{3}\right.$, $\mathrm{NH}_{4} \mathrm{Cl}$ and $\left.\left(\mathrm{NH}_{4}\right)_{2} \mathrm{SO}_{4}\right)$ was also attempted. The mineral salt solution used was devoid of $\left(\mathrm{NH}_{4}\right)_{2} \mathrm{SO}_{4}$, while studying the influence of nitrogen sources.

\section{Enzyme extraction}

After fermentation, the fermented material was mixed with distilled water and homogenized by keeping in a rotary shaker at $200 \mathrm{rpm}$ for $1 \mathrm{~h}$. Filtration was carried out through muslin cloth and the resultant filtrate was centrifuged for $20 \mathrm{~min}$ at $10,000 \mathrm{rpm}$ and $4^{\circ} \mathrm{C}$. The supernatant was used as the enzyme source for analytical experiments.

\section{Analytical procedures}

Assay for polygalacturonase

Polygalacturonase activity was determined according to Honda et al (4). Reaction mixture containing $0.5 \mathrm{~mL}$ of suitably diluted enzyme was incubated with $0.5 \mathrm{~mL}$ of $0.5 \%$ polygalacturonic acid (SIGMA) in $100 \mathrm{mM}$ McIlvaine buffer $(\mathrm{pH}$ 7.0 ) for $30 \mathrm{~min}$ at $50^{\circ} \mathrm{C}$. The reaction was interrupted by adding 2 $\mathrm{mL}$ of $100 \mathrm{mM}$ borate buffer (pH 9.0) followed by $1 \mathrm{~mL}$ of $1 \%$ cyanoacetamide. The mixture was immersed in a boiling water bath for $10 \mathrm{~min}$, cooled and read against a suitable blank at 276 nm using a spectrophotometer (Model UV PC 2401, Shimadzu Corporation, Japan). One unit (U) of polygalacturonase was defined as the amount of enzyme required to release $1 \mu \mathrm{mol}$ of galacturonic acid from polygalacturonic acid $\mathrm{min}^{-1}$ under the assay conditions.

\section{Estimation of biomass}

Biomass estimation was carried out by determining the $\mathrm{N}$ acetyl glucosamine content of the cell wall (17) and it was expressed as mg of glucosamine/g dry fermented matter.

\section{Dry weight determination}

A suitable amount of the fermented matter was dried in oven till constant weight and the dry weight of the sample was calculated.

\section{Banana fiber degumming}

Banana leaf sheath treatment was performed in $250 \mathrm{~mL}$ Erlenmeyer flasks and the treatment medium contained $10 \mathrm{~g}$ of wheat bran $(500-1000 \mu \mathrm{m})$ and $0.1 \mathrm{~g}$ of pectin, moistened by a salt solution of $(\mathrm{g} / \mathrm{L}) \mathrm{K}_{2} \mathrm{HPO}_{4}$ : 4 and $\mathrm{KH}_{2} \mathrm{PO}_{4}: 4$ (pH-6.0). The leaf sheath pieces $(30 \times 10 \times 2 \mathrm{~mm})$ were incorporated in the above medium, autoclaved for 45 minutes and inoculated with 5 $\mathrm{mL}$ of broth culture. Flasks were incubated at $30^{\circ} \mathrm{C}$ for three days and the wheat bran was washed off to take out the leaf sheath. The treated leaf sheath was re-fermented for another three days in fresh solid-state medium. Wheat bran was washed off and the fiber bundles were separated by hand stripping.

\section{Fiber quality}

Tensile strength of the fiber bundles was checked using Hounsfield test equipment (Model 5K-S). Diameter of the 
bundles was recorded with an optical microscope. Surface characteristics of the fiber bundles were analyzed with the help of scanning electron micrographs.

\section{RESULTS}

\section{Optimization of culture parameters}

Different culture parameters were optimized for the enhancement of polygalacturonase production by $S$. lydicus. Substrate selection was carried out earlier where wheat bran was found to be the best one (6). The optimum particle size of wheat bran for polygalacturonase production was in the range of 500$1000 \mu \mathrm{m}$. A decline in enzyme production was observed above and below the optimum particle size (Fig. 1). The initial moisture content is one of the most critical parameters for the successful operation of solid-state fermentation (SSF) (3). In the present investigation, $70 \%$ moisture was found to be the best for polygalacturonase production (Fig. 2). Moisture content of 80 to $90 \%$ is detrimental for the survival of actinomycetes. As evident from Figure 3, the highest enzyme activity was recorded when the $\mathrm{pH}$ of the moistening solution was 6.0, as compared to the control ( $\mathrm{pH}$ 7.0). Although the optimum $\mathrm{pH}$ was found to be 6.0, considerable production was detected in all sets of experiments. To find out the most favourable inoculum density, inoculum size was varied from $6.25 \times 10^{4}$ to $3.75 \times 10^{5} \mathrm{CFU}$ and the control with $1.25 \times 10^{5} \mathrm{CFU}$ was the best (Fig. 4). Fig. 5 demonstrates the effect of incubation temperature on polygalacturonase production by S. lydicus and the optimum temperature was $30^{\circ} \mathrm{C}$.

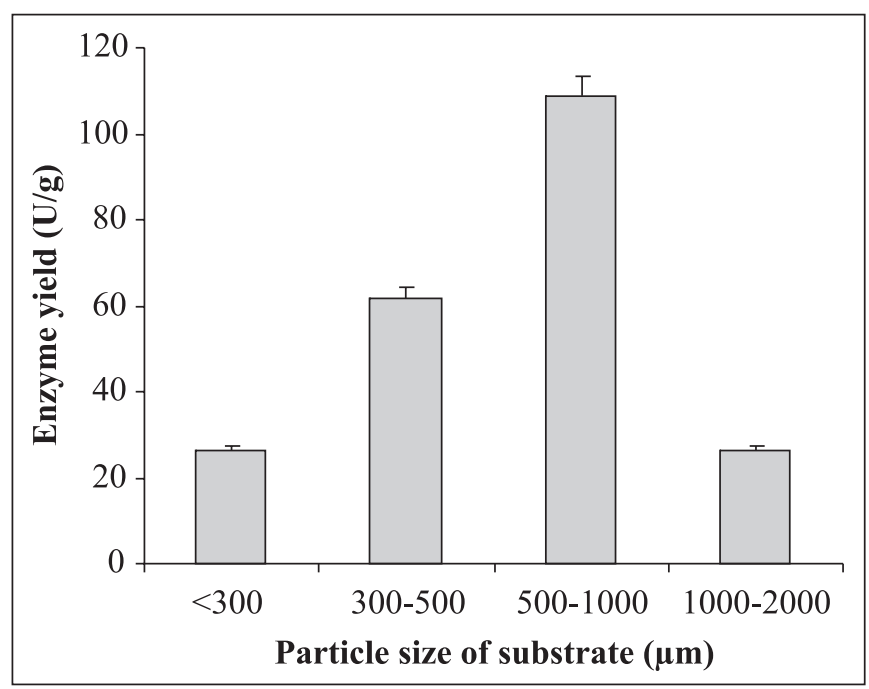

Figure 1. Effect of particle size of the substrate on enzyme production. Particle size of wheat bran was varied from $>300$ $2000 \mu \mathrm{m}$. The other culture conditions were moisture: $50 \%$; $\mathrm{pH}$ of the mineral salt solution: 7.0 ; inoculum size: $5 \mathrm{~mL}$ and temperature: $30^{\circ} \mathrm{C}$.

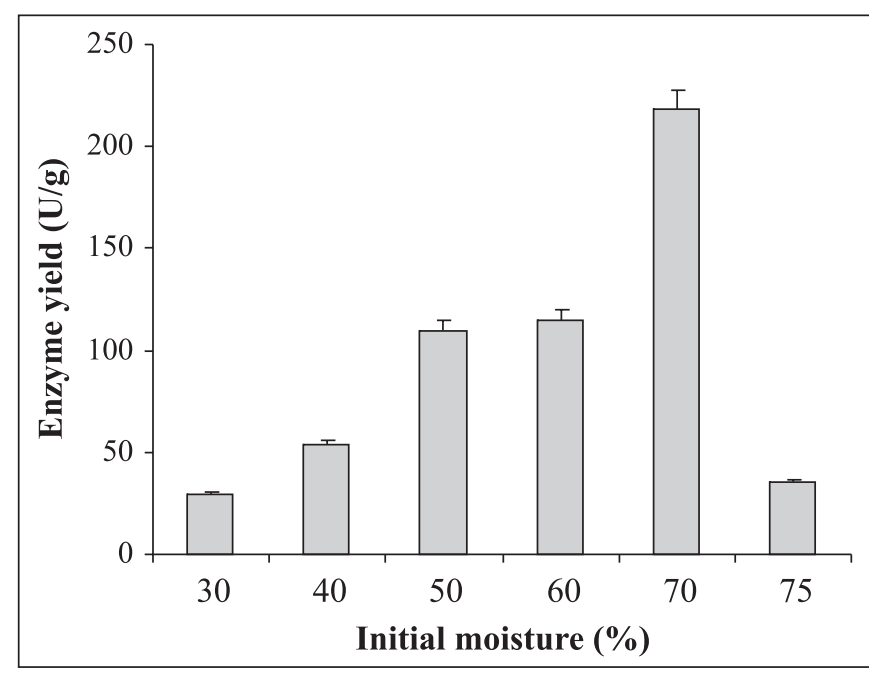

Figure 2. Impact of initial moisture content of the medium on polygalacturonase yield. Initial moisture content of the medium was adjusted from 30 to $75 \%$. The other culture conditions were particle size of wheat bran: $500-1000 \mu \mathrm{m}$; $\mathrm{pH}$ of the mineral salt solution: 7.0 ; inoculum size: $5 \mathrm{~mL}$ and temperature: $30^{\circ} \mathrm{C}$.

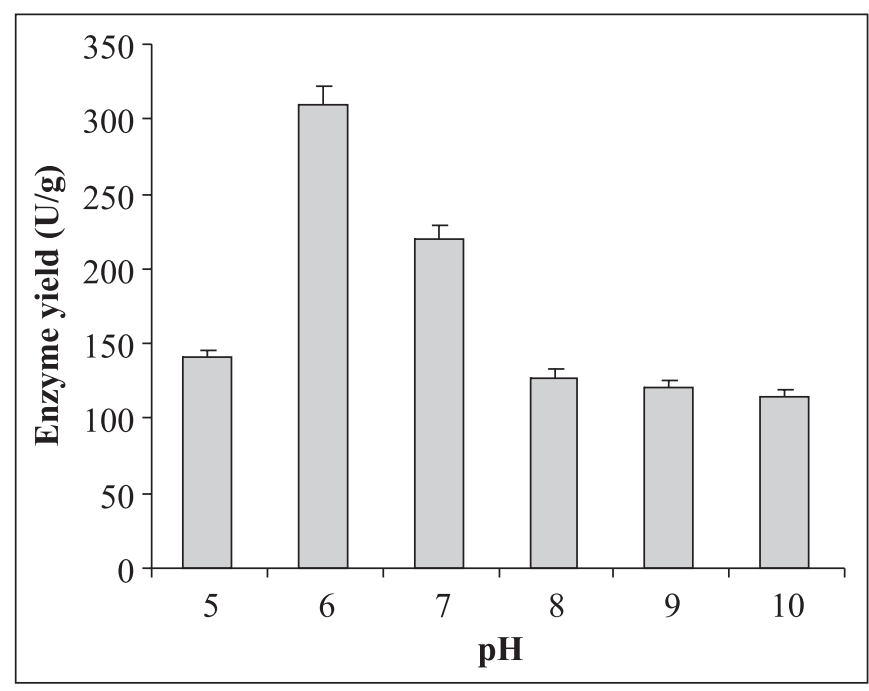

Figure 3. Influence of $\mathrm{pH}$ of the moistening solution on enzyme yield. $\mathrm{pH}$ of the moistening solution was altered from $\mathrm{pH} 5.0$ to $\mathrm{pH}$ 10.0. The other culture conditions were particle size of wheat bran: $500-1000 \mu \mathrm{m}$; moisture: $70 \%$; inoculum size: $5 \mathrm{~mL}$ and temperature: $30^{\circ} \mathrm{C}$.

\section{Optimization of nutritional parameters}

Among the various carbon additives, pectin was identified as the most favoured supplement (Fig. 6). Similar result has been reported in the case of Aspergillus japonicus where the 
maximum pectinolytic activity was observed in the presence of pectin (19). As illustrated in Fig. 7, none of the nitrogen supplements could augment enzyme yield.

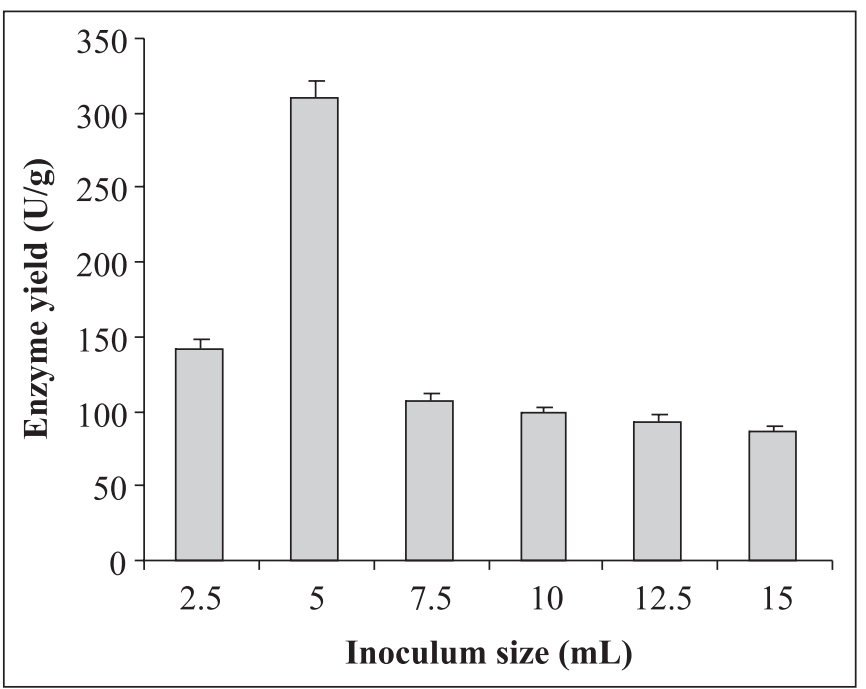

Figure 4. Effect of inoculum size on polygalacturonase yield. Inoculum density was varied from $2.5 \mathrm{~mL}$ to $15 \mathrm{~mL}\left(2.5 \times 10^{4}\right.$ $\mathrm{CFU} / \mathrm{mL}$ ). The other culture conditions were particle size of wheat bran: $500-1000 \mu \mathrm{m}$; moisture: $70 \%$; $\mathrm{pH}$ of the mineral salt solution: 6.0 ; and temperature: $30^{\circ} \mathrm{C}$.

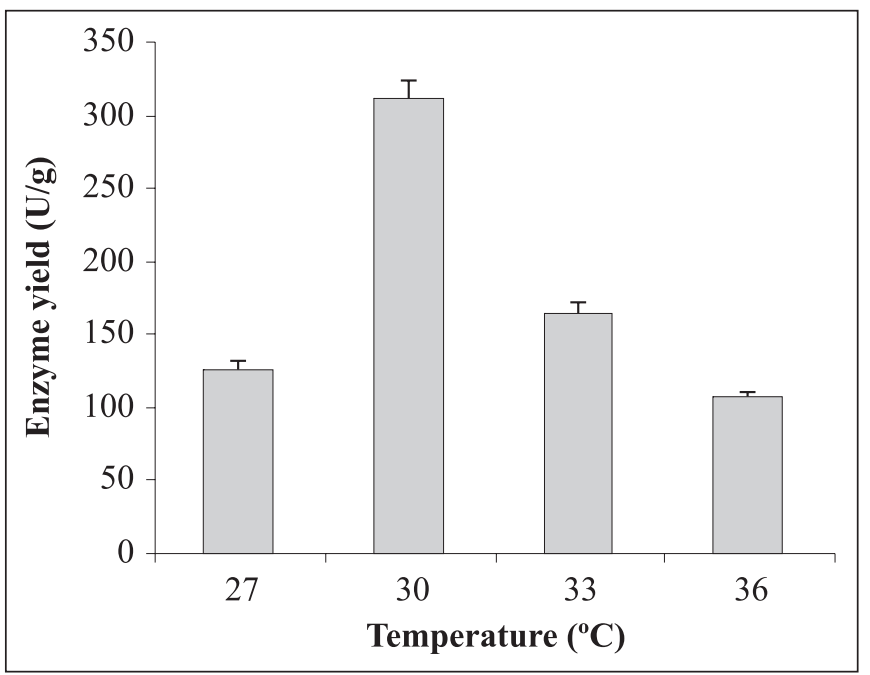

Figure 5. Influence of incubation temperature on enzyme production. The inoculated medium was incubated at different temperatures from $27-36^{\circ} \mathrm{C}$. The other culture conditions were particle size of wheat bran: $500-1000 \mu \mathrm{m}$; moisture: $70 \%$; $\mathrm{pH}$ of the mineral salt solution: 6.0 and inoculum size $5 \mathrm{~mL}$.

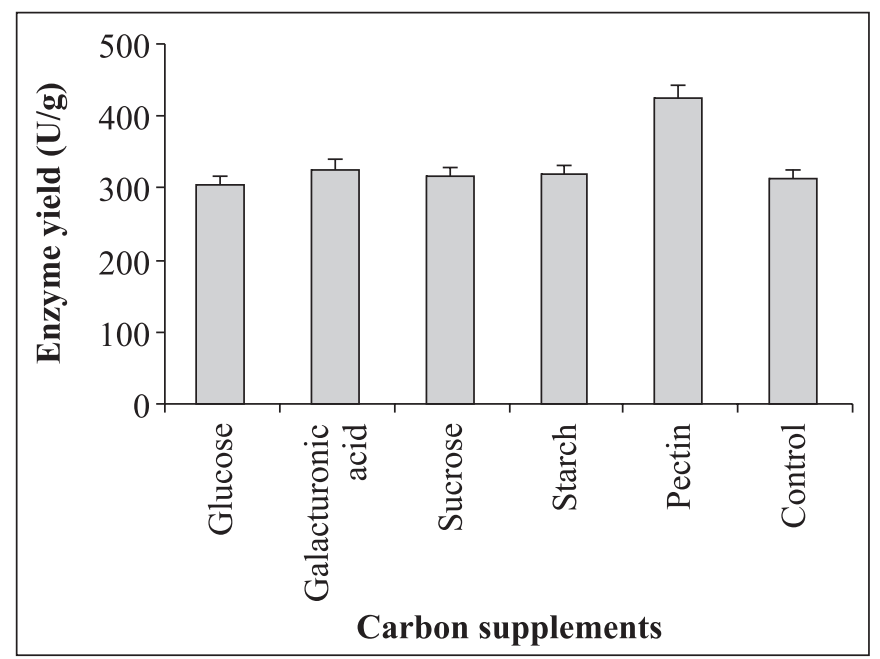

Figure 6. Effect of carbon supplements on polygalacturonase yield. The production medium was supplemented with glucose, galacturonic acid, sucrose, starch and pectin. The culture conditions were particle size of wheat bran: 500-1000 $\mu \mathrm{m}$; moisture: $70 \%$; $\mathrm{pH}$ of the mineral salt solution: 6.0 ; inoculum size $5 \mathrm{~mL}$ and temperature $30^{\circ} \mathrm{C}$.

\section{Evaluation of fermentation time}

Evaluation of fermentation time was conducted at $12 \mathrm{~h}$ interval, adopting the optimized conditions (Fig. 8) and the maximum enzyme activity was recorded at $72 \mathrm{~h}(425 \mathrm{U} / \mathrm{g})$. Biomass in terms of $\mathrm{N}$-acetyl glucosamine concentration showed a steep increase from 12 to $72 \mathrm{~h}$ and thereafter a steady state was maintained.

\section{Banana fiber degumming}

A two-step fermentative process was employed to extract the fiber bundles from fresh pseudostem of banana. The time required for the novel solid-state fermentative process was only six days. Scanning electron micrographs of the bundle was taken after biological extraction. Removal of the non-cellulosic gummy wastes was extremely good as compared to the control (fiber bundle obtained from fresh leaf sheath by hand stripping was considered as the control) (Fig. 9). Tensile strength of the biologically extracted fiber bundle was as good as the control (Table 1). Fiber bundles with the same diameter were selected for mechanical testing to avoid any false information.

\section{DISCUSSION}

\section{Effect of culture parameters on enzyme production}

SSF is an attractive tool for the production of enzymes because of its higher productivity, lower capital and operating costs, lower space requirements, simpler equipment and easier downstream processing compared to that of submerged 


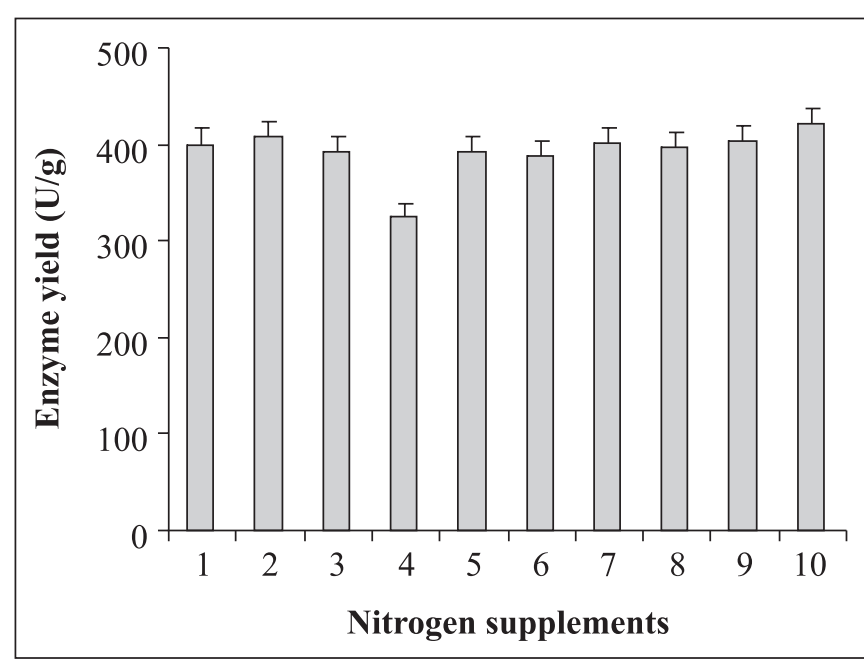

Figure 7. Supplementation of nitrogen sources. 1 yeast extract, 2 peptone, 3 urea, 4 corn steep solids, $5\left(\mathrm{NH}_{4}\right)_{2} \mathrm{HPO}_{4}, 6 \mathrm{KNO}_{3}, 7$ $\mathrm{NH}_{4} \mathrm{HCO}_{3}, 8 \mathrm{NH}_{4} \mathrm{Cl}, 9\left(\mathrm{NH}_{4}\right)_{2} \mathrm{SO}_{4}, 10$ control (without nitrogen supplement). The culture conditions were particle size of wheat bran: $500-1000 \mu \mathrm{m}$; moisture: $70 \%$; $\mathrm{pH}$ of the mineral salt solution: 6.0 ; inoculum size $5 \mathrm{~mL}$ and temperature $30^{\circ} \mathrm{C}$ with $1 \%$ pectin as carbon supplement. The mineral salt solution used for the experiment was devoid of $\left(\mathrm{NH}_{4}\right)_{2} \mathrm{SO}_{4}$.

Table 1. Properties of banana fiber bundles. Biologically extracted fiber bundles were as good as the control (Control: fiber bundle obtained from fresh leaf sheath by hand stripping was considered as the control. Biologically extracted fiber bundle: fiber bundles were hand stripped after biological treatment).

\begin{tabular}{ccc}
\hline $\begin{array}{c}\text { Fiber } \\
\text { properties }\end{array}$ & $\begin{array}{c}\text { Biologically } \\
\text { extracted fiber } \\
\text { bundle }\end{array}$ & Control \\
\hline Tensile Strength $(\mathrm{MPa})$ & 133 & 132 \\
Maximum force $(\mathrm{N})$ & 2.35 & 2.33 \\
Diameter $(\mathrm{mm})$ & 0.15 & 0.15 \\
\hline
\end{tabular}

fermentation (SmF) (14). The major factors that affect microbial synthesis of enzymes in a SSF system include selection of a suitable substrate, water content of the substrate, size of inoculum, temperature etc (12). Particle size of the substrate was found to be one among the crucial factors affecting enzyme production. The results of the present study indicating an optimum particle size of 500-1000 $\mu \mathrm{m}$ for polygalacturonase production can be correlated to the fact that the larger particle size decreases the enzyme production due to the reduction in

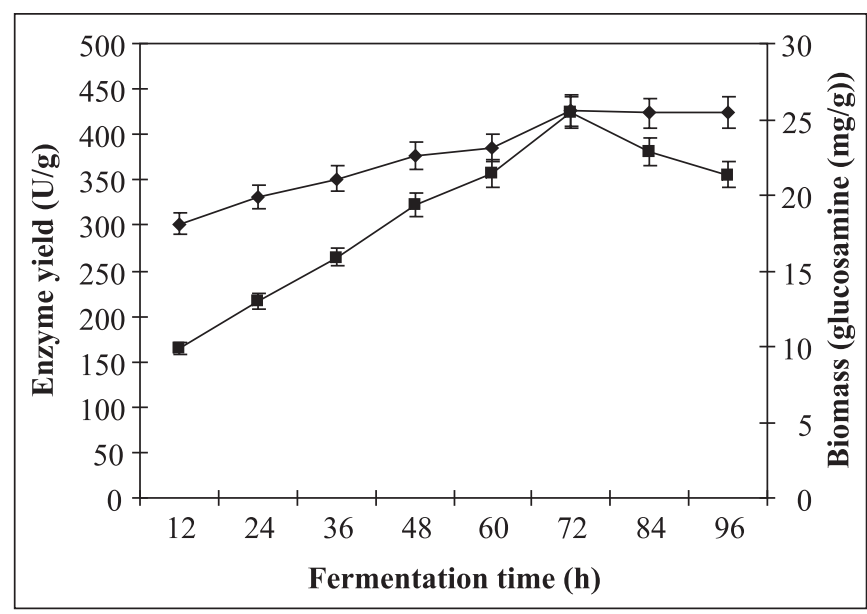

Figure 8. Time course of polygalacturonase production. Enzyme yield was monitored at regular intervals. (ם) Enzyme activity (U/g), ( ) Biomass (glucosamine (mg/g)). The culture conditions were particle size of wheat bran: $500-1000 \mu \mathrm{m}$; moisture: $70 \%$; $\mathrm{pH}$ of the mineral salt solution: 6.0 ; inoculum size $5 \mathrm{~mL}$ and temperature $30^{\circ} \mathrm{C}$ with $1 \%$ pectin as carbon supplement.
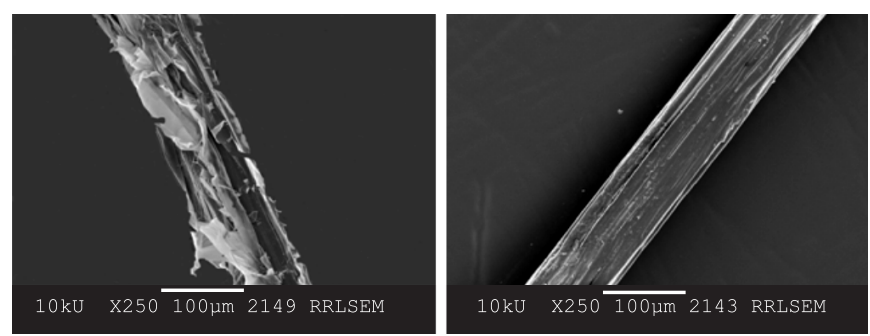

Figure 9. Scanning electron micrographs of banana fiber bundles; A. Control: fiber bundle obtained from fresh leaf sheath by hand stripping was considered as the control. B. Biologically extracted fiber bundle: fiber bundles were hand stripped after biological treatment.

total surface area while the smaller particle size reduces enzyme yield due to the diminution in the porosity of the medium. Initial moisture level of the medium also acts as a controlling factor for enzyme production. Low moisture level leads to reduced solubility of the nutrients of the solid substrate, lower degree of swelling and higher water tension (21) and hence, affects growth and metabolism of the organism (9). Moisture level above optimum causes decrease in the porosity, alteration in the wheat bran particle structure, gummy texture, low oxygen transfer etc (15). An extrinsic parameter, such as $\mathrm{pH}$, acts synergistically with other physical parameters in addition to being a regulatory parameter in biotechnological processes (10). However, in a solid-substrate medium, the $\mathrm{pH}$ of the mineral salt solution does 
not possess a profound impact on enzyme production as the substrate itself has a $\mathrm{pH}$ of its own. The amount of inoculum added to the fermentation medium has significant effect on growth and enzyme production. Lower inoculum density than the optimum may not be sufficient to initiate growth and to produce the required biomass, whereas higher inoculum can cause fierce competition for nutrients (9). Incubation temperature is a key factor affecting growth and metabolism of microbes as the activity of metabolic enzymes is directly influenced by temperature of the microenvironment. S. lydicus is mesophilic in nature with a growth temperature range of $15-42^{\circ} \mathrm{C}(7)$. When a mesophilic culture is concerned, very low temperature may not trigger the metabolism of the organism while very high temperature results in the denaturation of metabolic enzymes.

\section{Effect of nutrient supplementation on enzyme production}

Solid substrate not only serves as anchorage for the cells but also supplies the nutrients to the microbial cultures growing in it (13). However, some of the nutrients in the solid substrate may be available in sub optimal concentrations, or even not present in the substrate. In such cases, it would be necessary to supplement them externally (8) to enhance growth and subsequently enzyme production. In the present study, all the carbon additives except pectin and galacturonic acid could function only as nutrient supplements where as pectin and galacturonic acid acted both as nutrients as well as inducers. Both of them have been reported as inducers for polygalacturonase production (18). Normally galacturonic acid should have an inhibitory effect on enzyme production, as it is the end product of hydrolysis of pectin. But, unlike SmF, SSF system is much more resistant to catabolic repression (20). The results of nitrogen supplementation indicated that wheat bran, with $16 \%$ protein (5) in its composition, could supply the required nitrogen for the growth of the organism.

\section{Evaluation of fermentation time}

Enzyme yield has been increased considerably ( 3.9 fold) as compared to the initial medium (6). However, the hour of maximum enzyme production remained the same and biomass estimation led to the conclusion that the enzyme production by S. lydicus was growth associated.

\section{Banana fiber degumming}

An ecofriendly process for the simultaneous extraction and degumming of banana fibers was developed under solid state cultivation utilizing the ability of $S$. lydicus to produce polygalacturonase. Fiber quality is related to the length of the fiber as well as its properties (2). Length of the fiber bundle is an important factor for textile and yarn industries. In the current methodology, the required length can be achieved by varying the length of the leaf sheath pieces subjected for fermentation. The chemical composition of both biologically and mechanically extracted fibers exhibits a similar pattern (2). Hemicelluloses and pectins are the major type of gummy materials present on the outer walls of banana fiber bundles and hence the biological action does not modify the chemical composition of inner elementary fibers constitutive of the bundles, which are mainly composed of cellulose, lignin and some amount of hemicellulose (2). Biological natural retting, with an exposure time from 10 to 30 days, has been reported to obtain banana fiber bundles of different length. The tensile strength of the fiber bundles has been decreasing upon increasing biological extraction time (2) indicating the necessity of decreasing the duration of the process. The processing time required for the present method was only six days solving the above problem to a great extent. Enzyme treatment of banana leaf sheath is a good strategy compared to simultaneous fermentation as it may further reduce the duration of the treatment. The treatment of hand stripped banana fiber bundles has already been attempted with polygalacturonase obtained from S. lydicus (7). But the yield is more in biological extraction than the other strategy with hand stripping and processing (2) and so the present study was focused on biological extraction of banana fiber bundles. The present method is advantageous as compared to chemical extraction procedures as environmental pollution can be avoided. The newly developed ecofriendly methodology, which can be operated with less infrastructure and space within a short period of time, is expected to be a promising one in the field of plant fiber extraction and processing.

\section{ACKNOWLEDGEMENTS}

The authors are grateful to CSIR, India for the fellowship awarded to NJ.

\section{RESUMO}

\section{Novo processo para a extração e simultânea degomagem de fibras de banana}

Vários parâmetros de processo de produção de poligalacturonase por Streptomyces lydicus por fermentação em estado sólido foram otimizados. O tamanho ótimo de partícula de farelo de trigo para a produção de poligalacturonase esteve na faixa de 500 a $1000 \mathrm{~mm}$. O teor inicial de umidade de $70 \%$ foi o melhor para a produção da enzima. O inóculo inicial mais adequado foi de $1,25 \times 10^{5} \mathrm{UFC} / \mathrm{mL}$ e a temperatura ótima de incubação foi $30^{\circ} \mathrm{C}$. A adição de fontes de carbono resultou em aumento de $37 \%$ no rendimento da enzima ( $425 \mathrm{U} / \mathrm{g})$, enquanto que a suplementação com nitrogênio não melhorou o rendimento. O rendimento máximo da enzima foi obtido em $72 \mathrm{~h}$. A otimização resultou em um aumento de 3,9 vezes na quantidade de enzima produzida inicialmente $(108,5 \mathrm{U} / \mathrm{g})$. A fermentação em estado-sólido foi eficiente para o desenvolvimento de um novo 
processo de extração e simultânea degomagem. Streptomyces lydicus foi cultivado em meio de farelo de trigo acrescentado de fragmentos de folhas de banana, sendo os feixes de fibras separados após um processo de fermentação em dois passos.

Palavras-chave: Degomagem de fibras de banana, fermentação em estado sólido, poligalacturonase, Streptomyces lydicus, farelo de trigo

\section{REFERENCES}

1. Dutta, A.C. (1980) The tissue. In: Dutta, A.C. (ed). A Class-Book of Botany. Oxford University Press, London, p. 182-194.

2. Ganan, P.; Zuluaga, R.; Velez, J.M.; Mondragon, I. (2004) Biological natural retting for determining the hierarchical structuration of banana fibers. Macromol. Biosci., 4, 978-983.

3. Gonzalez, J.B.; Tomasini, A.; Viniegra-Gonzalez, G.; Lopez, J. (1988) Penicillin producton by solid state fermentation. Biotechnol. Lett., 10, 793-798.

4. Honda, S.; Nishimura, Y.; Takahashi, M.; Chiba, H.; Kakehi, K. (1982) A manual method for the spectrophotometric determination of reducing carbohydrates with 2-cyanoacetamide. Anal. Biochem., 119, 194-199.

5. Idris Wisal, H.; Babiker Elfadi, E.; El Tinay Abdullahi, H. (2003) Fractionation, solubility and functional properties of wheat bran proteins as influenced by $\mathrm{pH}$ and/or salt concentration. Nahrung., 47, 425-429.

6. Jacob, N.; Prema, P. (2006) Influence of mode of fermentation on polygalacturonase production by a novel strain of Streptomyces lydicus. Food Technol. Biotechnol., 44, 263-267.

7. Jacob, N.; Niladevi, K.N.; Anisha, G.S.; Prema, P. (2006) Hydrolysis of pectin: an enzymatic approach and its application in banana fiber processing. Microbiol. Research, doi:10.1016/j.micres.2006.07.016.

8. Kashyap, D.R.; Soni, S.K.; Tewari, R. (2003) Enhanced production of pectinase by Bacillus sp. DT7 using solid state fermentation. Bioresour. Technol., 88, 251-254.

9. Kaur, G.; Satyanarayana, T. (2004) Production of extracellular pectinolytic, cellulolytic xylanolytic enzymes by thermophilic mould
Sporotrichum thermophile Apinis in solid state fermentation. Indian J. Biotechnol., 3, 552-557.

10. Lonsane, B.K.; Ramesh, M.V. (1990) Production of bacterial thermostable $\alpha$-amylase by solid state fermentation; A potential tool for achieving economy in enzyme production and starch hydrolysis. Adv. Appl. Microbiol., 35, 1-56.

11. Mohanty, A.; Mishra, M.; Hinrichsen, G. (2000) Biofibres, biodegradable polymers and biocomposites:An overview. Macromol. Mater. Eng., 276/277, 1-24.

12. Pandey, A.; Selvakumar, P.; Soccol, C.R.; Nigam, P. (1999) Solidstate fermentation for the production of industrial enzymes. Curr. Sci., 77, 146-162.

13. Pandey, A.; Soccol, C.R.; Mitchell, D. (2000) New developments in solid state fermentation. I. Bioprocesses and products. Process Biochem., 35, 1153-1169.

14. Pandey, A.; Soccol, C.R.; Nigam, P.; Soccol, V.T. (2000) Biotechnological potential of agroindustrial residues. I: sugar cane begasse. Bioresour. Technol., 74, 69-80.

15. Raimbault, M.; Alazard, D. (1980) Culture method to study fungal growth in solid-state fermentation. Eur. J. Appl. Microbiol. Biotechnol., 9, 199-209.

16. Said, S.; Fonseca, M.J.V.; Siessere, V. (1991) Pectinase production by Penicillium frequentans. World J. Microbiol. Biotechnol., 7, 607608.

17. Sakurai, Y.; Lee, T.H.; Shiota, H. (1977) On the convenient method for the glucosamine estimation in koji. Agric. Biol. Chem., 41, 619624.

18. Solís-Pereira, S.; Torres, E.F.; Viniegra-González, G.; Gutiérrez-Rojas, M. (1993). Effects of different carbon sources on the synthesis of pectinase by Aspergillus niger in submerged and solid state fermentations. Appl. Microbiol. Biotechnol., 39, 36-41.

19. Teixeira, M.F.S.; Filho, J.L.L.; Durán, N. (2000) Carbon sources effect on pectinase production from Aspergillus japonicus 586. Braz. J. Microbiol., 31, 286-290.

20. Viniegra-González, G.;Torres, E.F. (2006) Why solid-state fermentation seems to be resistant to catabolite repression? Food Technol. Biotechnol., 44, 397-406.

21. Zadrazil, F.; Brunnet, H. (1982) Solid state fermentation of lignocellulose containing plant residues with Sporotrichum pulverulentum and Dichomitus squales Reid. Eur. J. Appl. Microbiol., $16,45-51$. 